\title{
Factor that Influence the Implementation of Quality Assurance Programs for Hospital-based Long Term Contraceptive Services
}

\author{
Azrul Azwar
}

\begin{abstract}
Abstrak
Untuk lebih meningkatkan mutu pelayanan kontrasepsi jangka panjang (Alat Kontrasepsi Dalam Rahim, susuk KB, dan sterilisasi) di Indonesia secara lebih sistematis dan berkelanjutan, diperkenalkanlah Program Menjaga Mutu (Quality Assurance Program) di 12 Rumah Sakit (RS) terpilih yang menyelenggarakan pelayanan keluarga berencana di Jakarta.Tujuan dilaksanakannya penelitian ini adalah untuk mengetahui faktor-faktor yang mempengaruhi keberhasilan dan/ataupun kegagalan pelaksanaan Program Menjaga Mutu tersebut. Setelah melaksanakan kegiatan Program Menjaga Mutu selama sekitar 12 bulan, ditemukan 9 RS $(75,0 \%)$ berhasil melaksanakan Program Menjaga Mutu, sedangkan sisanya sebanyak 3 RS $(25,0 \%)$ mengalami kegagalan. Dari 12 faktor yang diduga mempengaruhi pelaksanaan Program Menjaga Mutu, yakni peranan ketua Tim, pengetahuan anggota Tim, minat anggota Tim, tanggungjawab anggota Tim, kerjasama anggota tim, perhatian pimpinan RS, kerjasama dengan fasilitator, berperanserta anggota Tim, beban kerja anggola Tim, frekuensi supervisi pimpinan, frekuensi umpan balik pimpinan, serta frekuensi bimbingan berkala dari fasilitator, 7 diantaranya terbukti mempunyai pengaruh terhadap pelaksanaan Program Menjaga Mutu. Ketujuh faktor tersebut adalah peranan ketua Tim, tanggungjawab anggota Tim, kerjasama anggota Tim, minat anggota Tim, perhatian pimpinan, kerjasama dengan fasilitator, serta jumlah supervisi pimpinan.
\end{abstract}

\begin{abstract}
In order to further improve the quality of hospital based long term contraceptive services (IUD, implant, and sterilization) in a more systematic and continous way in Indonesia, a Quality Assurance Program (QA) was introduced in twelve selected hospitals in Jakarta that had family planning programs. This study was conducted in order to determine which factors influence the implementation of the Quality Assurance Program in the twelve selected hospitals in Jakarta. After having conducted this Quality Assurance Program for about 12 months, it was found that nine hospitals (75.0\%) were able to implement the Quality Assurance Program while the remaining three hospitals (25.0\%) failed to implement the quality assurance program. For this study, twelve factors were identified as possibly having an influence on the implementation of the QA in these twelve hospitals, namely the role of the QA team leader, knowledge of the $Q A$ team members, responsibility of the $Q A$ team members, interest of the QA team members, team-work of the QA team members, attention of the hospital director, cooperation with the facilitator, participation of the QA team members, workload of the QA team members, frequency of supervision by the hospital director, frequency of feedback from the hospital director, and the amount of periodic guidance by the facilitator. The results of the study showed that out of these twelve factors seven factors were shown to have siqnificant influence on the successful implementation of the Quality Assurance Programs. These seven factors were the role of the $Q A$ team leader, the responsibility of the $Q A$ team members, the team-work of the $Q A$ team members, the interest of the $Q A$ team members, the attention of the hospital director, the good cooperation with the facilitator, and the amount of supervision by the hospital director.
\end{abstract}

Keyword : Quality Assurance Program, hospital based long term contraceptive services, factors influenced.

In order to further improve the quality of hospital based long term contraceptive services (IUD, implant, sterilization $)^{1}$ in a more systamatic and countinous ways in Indonesia, a Quality Assurance Program (QAP) ${ }^{2-7}$ was introduced in twelve selected hospital in Jakarta that provided family planning services. The QAP

Department of Community Medicine, Faculty of Medicine University of Indonesia, Jakarta, Indonesia model that was introduced was developed based on the recomendation of an analytical study previously conducted. The model utilizes three integrated management principles, namely team work, ${ }^{8}$ group decision making, and the use of a problem solving cycle. ${ }^{10}$ Prior to the model's implementation, three intervention programs were carried out, namely an orientation training for hospital directors, ${ }^{11-13}$ a QA training program for all QA team members, ${ }^{14}$ and a one day orientation seminar on QAP for the entire hospital staff. $^{15}$ 
To assist the QA team members in the implemention of the quality assurance activities, especially for technical aspects, an external facilitator was provided for each hospital. The external facilitator was requested to visit the hospital at least once a month.

After approximately twelve months of QA activity implemention at the twelve selected hospitals, it was found that nine of these twelve hospitals $(75,0 \%)$ were able to implement the QA activities while the remaining three hospitals $(25 \%)$ failed to implement the $\mathrm{QA}$ activities. The main question then is what factors influenced the implementation of the QAP in these hospitals?

The aim of this study was to determine which factors influenced the successful implementation of the QAP in the twelve hospitals.

\section{METHODS}

The study outcome to be measured was the completion of the quality assurance program (dependent variable). To obtain information about various independent variables that influenced the QAP, data was collected by using two means.

First, the QA team members were interviewed to obtain information about their opinion regarding the factors influenced the QAP. During these interviews seven factors were studied, namely the role of the QA team leader, the knowledge of the QA team members, the responsibility of the QA team members, the teamwork of QA team members, the interest of QA team members, the attention of the hospital directors, and the cooperation with the facilitator.

Second, all QAP recording forms which were available in each hospital were reviewed. During this review, five factors were reviewed, namely the participation of QA team members, the workload of QA team members, the amount of supervision by the hospital director, the amount of feedback from the hospital director, and the amount of periodic guidance visits by the facilitator.

Interview with the QA team members was conducted using prepared questionaire that had already been pretested by the interviewers who have been trained on the background, objectives, and method of the study. It was noted that the total number of QA team members in the twelve study hospitals was 122 persons.

The collected data were processed, in two steps. ${ }^{16}$ First, descriptively, to obtain a description of all de- pendent and independent variables. Second, analytically, to evaluate the relationship between the dependent variables and the independent variables. For this, a bivariate statistic analysis was used, namely t-test, chi-square-test, and Fisher's Exact-test. Odds ratios were estimated by the method of maximum likelihood. The $95 \%$ confidence intervals (CI) were based on the standard error of coeffient estimates.

\section{RESULTS}

Interviews with $122 \mathrm{QA}$ team members resulted in data from 117 QA team members $(95.9 \%)$. Looking at the place of work of the QA team members, it was found out that out of the 117 QA team members interviewed, 81 of them $(69.2 \%)$ were working in the nine hospitals that were able to implement the QAP, whereas the remaining $30.8 \%$ of the team members worked in the three hospitals that failed to implement the QAP. Results of statistical analysis of the seven factors that influenced the implementation of QAP can be summarized as follows:

\section{Role of the QA team leader}

Interviews with $117 \mathrm{QA}$ team members found that 86 of the team members $(73.5 \%)$ stated that the role of QA team leader in impleneting QAP was supportive. The rest $31 \mathrm{QA}$ team members $(26.5 \%)$ stated that the role of QA team leader was not supportive. The results of the statistical analysis found that the role of QA team leader had a significant contribution to the implementation of QAP ( $p<0.05$; $O R=492: 1,87-13,18$ ).

\section{Knowledge of QA team members}

Interviews with $117 \mathrm{QA}$ team members found that 108 of the team members (92.3\%) stated that their knowledge regarding the theoritical and practical aspects of QAP was sufficient. The remaining of the nine team members $(7.7 \%)$ stated that the their knowledge was insufficient. The results of statistical analysis found that the know-ledge of the QA team members did not make a siqnifi-cant contribution to the implentation of QAP ( $>0.05 ; \mathrm{OR}=0.62: 0.08$ 3.45).

\section{Responsibility of QA team members}

Interviews with $117 \mathrm{QA}$ team members found out that 78 of the team members $(66.7 \%)$ stated that their responsibility to the QAP was high. The remaining 39 team member $(33.3 \%)$ stated that their responsibility were low. The results of statistical analysis found that the responsibility of team members had a siqnificant 
contribution to the implementation of QAP ( $\mathrm{p}<0.05$; $\mathrm{OR}=0.62: 0.08-3.45$ ).

\section{Team work of QA team members}

Interviews with $117 \mathrm{QA}$ team members found out that 81 of the team members $(69.2 \%)$ stated that their team work when implementing $Q A$ activities was good. The remaining 36 team members $(30.8 \%)$ stated that their team work was bad. The results of statistical analysis found that the team work of team member had a significant contributio $n$ to the implementation of QAP $(p<0.05 ; O R=94.24: 22.16-456.78)$.

\section{Interest of QA team members}

Interviews with 117 QA team members found out that 75 of the the team members $(64.1 \%)$ stated that their interest in QAP was high. The remaining 42 team members $(35.9 \%)$ stated that their interest was low. The results of statistical analysis found that the interest of team member had a signifi-cant contribution to the implemention of QAP ( $\mathrm{p}<0.05$; $\mathrm{OR}=155.13$ : 27.80 156.06).

\section{Attention of hospital directors}

Interviews with 117 QA team members found that 45 of the team members $(46.2 \%)$ stated that the attention of hospital directors toward QAP was high. The remaining of 63 team members $(53.8 \%)$ stated that this attention was low. The results of statistical analysis found that the attention of hospital directors had a significant contribution to the implemention of the QAP $(\mathrm{p}<0.05)$.

\section{Cooperation with facilitator}

Interviews with 117 QA team members found out that 111 of the team members $(94.9 \%)$ stated that their cooperation with the facilitator when implementing QAP was good. The remaining six team members $(5.1 \%)$ stated that this cooperation was bad. The results of statistical analysis found that the cooperation with the facilitator had a significant contribution to the implemention of the QAP $(p<0.05$; OR=12.90: 1.37 304.01).

Complete information regarding these seven factors can be seen in the Table 1 .

Table 1.' Results of interviews with quality assurance team members regarding the factors influencing the implementation of the quality assurance program

\begin{tabular}{|c|c|c|c|c|c|}
\hline Factors influenced & Completed & Not completed & $\mathrm{p}$ & odds ratio & $(95 \% \mathrm{CI})$ \\
\hline \multicolumn{6}{|c|}{ Role of QA team leader } \\
\hline a. supportive & 13 & 18 & 0.0002 & 4.92 & $(1.87-13.8)$ \\
\hline b. not supportive & 68 & 18 & & & \\
\hline \multicolumn{6}{|c|}{ Knowledge of QA team members } \\
\hline a. sufficient & 7 & 2 & 0.1719 & 0.62 & $(0.08-3.45)$ \\
\hline b. insufficient & 74 & 34 & & & \\
\hline \multicolumn{6}{|c|}{ Responsibility of QA team members } \\
\hline a. high & 3 & 36 & 0.0000 & - & - \\
\hline b. low & 78 & 0 & & & \\
\hline \multicolumn{6}{|c|}{ Team-work of QA team members } \\
\hline a. good & 5 & 31 & 0.0000 & 84.24 & $(22.16-456.78)$ \\
\hline b. bad & 76 & 5 & & & \\
\hline \multicolumn{6}{|c|}{ Interest of QA team members } \\
\hline a. high & 8 & 34 & 0.0000 & 155.13 & $(27.80-1156.06)$ \\
\hline b. low & 73 & 5 & & & \\
\hline \multicolumn{6}{|c|}{ Attention of hospital directors } \\
\hline a. high & 27 & 36 & 0.0000 & - & - \\
\hline b. low & 54 & 0 & & & \\
\hline \multicolumn{6}{|c|}{ Cooperation with facilitator } \\
\hline a. good & 1 & 5 & 0.0103 & 12.90 & $(1.37-304.01)$ \\
\hline b. bad & 80 & 31 & & & \\
\hline
\end{tabular}


Reviewed the records of the QA teams regarding the implementation activities of QAP found out the following results:

\section{Participation of team members}

Participation of QA team members in the QAP was calculated based on the percentage of QA team members involved actively in daily QA activities. It was found that the average percentage of QA team members involved actively for all twelve study hospitals was $59.2 \%$, for the nine successful hospitals $71.1 \%$, and for the three unsuccessful hospitals $43.8 \%$. The results concluded that the active participation of team members did not make a significant contribution to the successful implementation of QAP ( $p>0.05)$.

\section{Workload of QA team members}

The workload of QA team members was calculated based on types and numbers of activities performed routinely in the hospital. Using a special scoring technique system that was developed for this study, it was found that the average workload score of QA team members for all twelve study hospital was 16.6 , for the nine successful hospitals 16.9 , and for the three unsuccesful hospitals 15.7. The results concluded that the workload of QA team members had no significant contribution to the implementation of QAP $(\mathrm{p}>0.05)$.

\section{Supervision by hospital director}

Under this study, two hospital directors (16.7\%) never conducted supervision for the QAP in his/her hospital. The re maining ten hospital directors $(83.3 \%$ ) did conduct some supervision, with the amount of supervision ranging from 1 to 19 times. The average number of supervision for all twelve study hospitals was 6.9 times, for the nine successful hospitals 9,1 times, and for the three unsuccessful hospitals 0,3 times. The results show that the amount of supervision by hospital directors had a significant contribution to the successful implementation of QAP $(p<0.05)$.

\section{Feedback from hospital directors}

Similar to supervision, not all hospital directors ever provided his/her feedback regarding the implementation of QAP in his/her hospital. The total number of hospital directors that ever provided feedback was 10 persons $(83,3 \%)$. The average feedback given by hospital directors for all twelve study hospitals was 6.9 times, for the nine successful hospitals 9.0 times, and for the three unsuccessful hospitals 0.7 times. The results show that the number of feedback from hospital directors had not a significant influence for the successful implementation of QAP ( $p>0.05)$.

\section{Periodic guidance visit by the facilitator}

The average number of periodic guidance visit by the facilitator to all twelve study hospitals was 8.4 times, to the nine successful hospital 8.8 times, and to the three unsuccessful hospitals was 7 times. Result concluded that the amount of periodic guidance visits by the facilitator had no significant contibution to the successful implementattion of QAP $(p>0.05)$.

Complete information regarding the five factors that were shown to make a significant contribution to the successful implementation of QAP can be seen in Table 2 . Table 2 Results of evaluation of the recording form of the quality assurance teams regarding the factors influenced the implementa-
tion of the quality assurance program

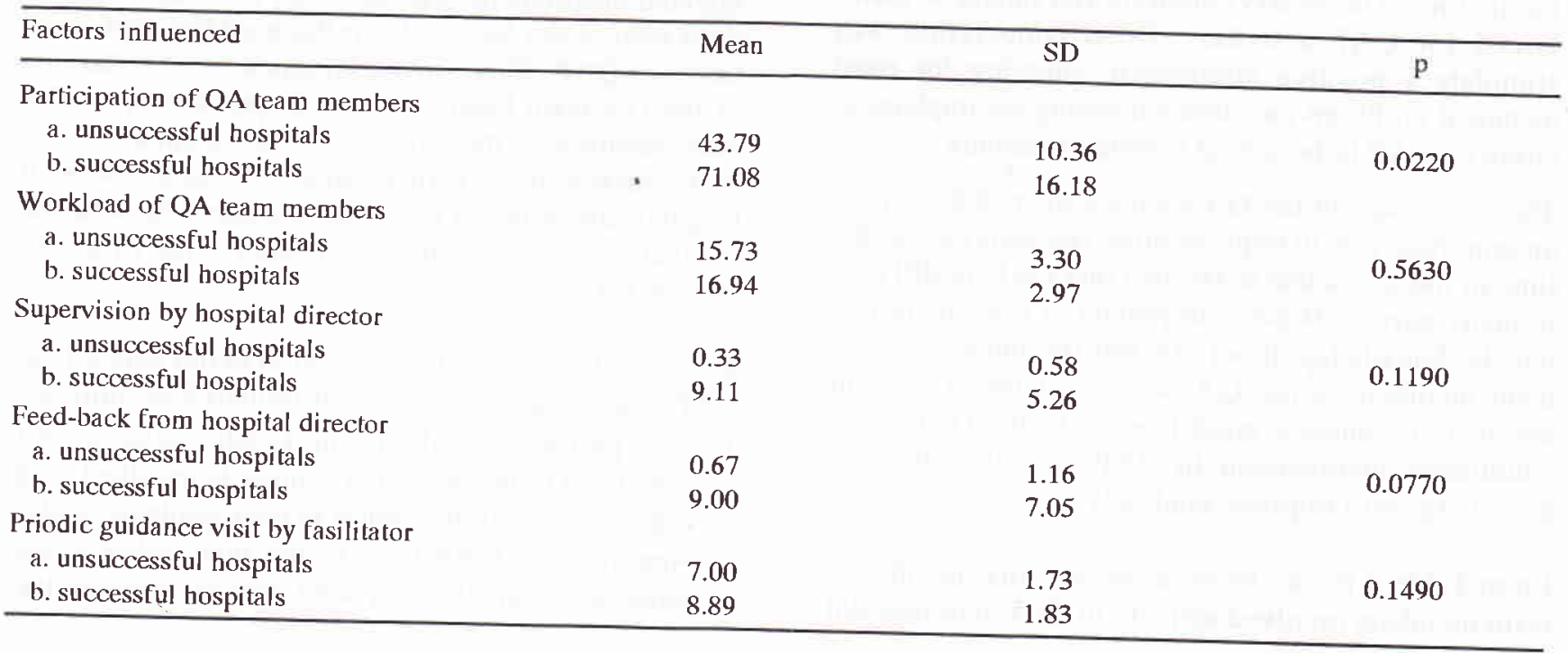




\section{DISCUSSION}

Looking at Table 1, it is clear that out of the seven factors that were thought to have an influence on the QAP, only six factors actually made a significant contribution to the successful inplementation of QA activities. These six factors were: 1 . role of $\mathrm{QA}$ team leader, 2. responsibility of QA team members, 3. team work of QA team members, 4. interest of QA team members, 5. attention of hospital directors, and 6. good cooperation with the facilitator.

The importance of the role of the QA team leader in the implementation of QAP activities is easy to understand since the QA team leader actually was the "engine" of the QAP. This study indicates that the three hospitals that failed to continue their QA activities did so mainly due to the fact that their QA team leaders was not able to participate actively in the QA activities. One of these three teams leaders was transfered to other job assignment, a second team leader left to continue his studies, and a third had no interest in QAP.

Also, the importance of the responsibility, team-work, and interest of QA team members, together with the attention of hospital directors, towards the successful implementation of QAP is also not difficult to understand since all of these factors actually reflected the commitment of the hospital staff and the directors. Many other studies have also concluded that the role of commitment, especially from the hospital director, was one of the important factors that determined the success of QAP prograns. ${ }^{11-13}$

This study found that good cooperation with a facilitator was important to the success of QAP. This finding is also easy to understand since it is known that good cooperation between QA team members and a facilitator is a necessary condition and should be maintained for QAP activities. Good cooperation will stimulate a positive atmosphere allowing for most technical problems encountered during the implementation of QAP to be solved together smoothly.

The knowledge of the QA team members did not play an important role in implementing $Q A$ activities at this time in Indonesia due to the fact that QAP is still new to many parties. What is important at this juncture is not the knowledge about $\mathrm{QA}$ but the interest of $\mathrm{QA}$ team members in the $\mathrm{QA}$ process. If the $\mathrm{QA}$ team members do show a good interest in the QAP, with countinous involvement in QAP activities, the QA knowledge will improve gradually.

From Table 2 it can be seen that the total number of team members involved actively in QAP activities did not have a significant influence on the successful implementation of QAP activities. Further investigation found that the team members that had low participation were the doctors. Although they were QA team members, they were not always able to join every QAP activities dur to other commitments. This experience tells us that the role of the doctors in QAP seems to be of less importance and the success of QAP seems not to be determined by active involvement of the doctors.

The fact that the workload of QA team members did not influence the success of QAP is reflected in normal daily life. On many occasions the person who has many activities is usually the person who is able to complete all of his/her assignments, based mainly on his/her interest in the assignments.

Also, the fact that the amount of supervision by the hospital director showns a positive impact on the success of QAP is logical due to the importance of supervision as one of the essential management function which should be performed properly by a good manager. $^{17}$

This study found that the amount of feedback from hospital directors did not make a significant contribution to the success of QAP. The possible explanation for this might be related to the status of QAP in Indonesia. Since QAP is still new in Indonesia not many people know about the program. Therefore to avoid misleading judgments, many hospital directors are reluctant to give feedback. As a result, there were no significant difference in amount of feedback between successful and unsuccessful study hospitals.

\section{CONCLUSION}

From the experiences implementing QAP in twelve selected hospitals in Jakarta, it can be concluded that there were seven factors that influenced the implementation of QAP. These seven factors were: 1 ) the role of the QA team leader, 2) the responsibility of QA team members, 3) the team work of QA team members, 4) the interest of QA team members, 5) the attention of hospital directors, 6) the good cooperation with the facilitator, and 7) the amount of supervision by hospital director.

Based on this conclusion, in order to better support the QAP, four suggestions can be formulated as follows:

1. To appoint a QAP Team Leader who is not scheduled to be transfered soon or is involved with other major activities such as post-graduate study. Appointing a QAP team leader who either is not going to be involved or who will be leaveing the 
facility soon will clearly jeopardize the countinous and proper implementation of QAP activities.

2. To utilize criteria for apppointing QA team members that include staff that shown strong responsibility, have a strong spirit of team work, and have an interest in QA.

3. To help quarantee the successful implementation of QAP activities the hospital director should pay adequate attention to the QAP including conducting regular supervision.

4. To gua rantee the success of QAP, it is recomended to use a facilitator that is capable of building good cooperation with the QA team members.

\section{REFERENCES}

1. Badan Koordinasi Keluarga Berencana Nasional. Rapat penelaahan dan penyusunan rancangan Gerakan KB Tahun 1995/1996; 1995 Oct 1 - Nov 1; Ujung Pandang. Jakarta: BKKBN, 1995.

2. Donabedian A. Exploitation in quality and monitoring. Ann Arbor, Michigan: Health Administration Press, 1980

3. Swelan A. Quality Assurance Key to Effective Family Planning Services. Cairo: EJMDA, 1990.

4. Palmer H. Ambulatory health care principle and practice in America. Chicago. American Hospital Association, 1983.

5. Ruelas E, Frenk J. Framework for analysis of Quality in Transition: The case of Mexico. Aust Clin Rev 1989; 9:9-16.
6. Brown LD, Franco LM, Rafeh N, Hatzell T. Quality assurance of health care in developing countries. Bethesda MD: Center for Human Services, 1990.

7. Maltos JJ, Keller C. Quality Assurance: A manual for family planning agencies. San Fransisco: James Bowman Agencies, 1989.

8. Hodgetts RM, Cascio DM. Modern heal th care administration. New York: Academic Press, 1983.

9. Wolper LF, Pena JJ, editor. Health care Administration. Principle and Practice. Rockville: Aspen Publishers Inc, 1987.

10. Galbraith MW, editor. Adult Learning Methods : A Guide for Effective Instruction. Florida: Krieger Publishing, 1990.

11. Peters TJ, Austin NK. A Passion for Excellence: The Leadership Difference. New York:Random House, 1985.

12. McLoughlin J. Quality Assurance Program. New York: Planned Parenthood Federation of America Inc, 1984.

13. Simmons R, Simmons GB. Moving Toward a Higher Quality of Care: Challenges for Management. In : Jain AK, editor. Managing Quality of Care in Population Programs. Connecticut: Kumarian Press Inc, 1992: 23-34.

14. Cocheu T. Training for Quality Improvement. Train Dev J $1989 ; 56-62$.

15. Al-Assaf AF, Schmele JA. The textbook of Total Quality in Healthcare. Florida: St. Lucie Press,1993.

16. Colton T. Statistics in Medicine. London: Little Brown and Company, 1974.

17. Levey S, Loomba P. Health care administration, a managerial prospective. Phil: JB LippincottComp, 1973. 